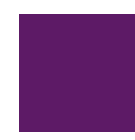

\title{
Lodz
}

Ec on omics

Working

Papers

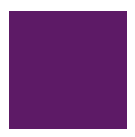

\section{DOES THE EURO INCREASE THE COMPLEXITY OF EXPORTED GOODS? THE CASE OF ESTONIA}

Piotr Gabrielczak

Tomasz Serwach 


\title{
Does the euro increase the complexity of exported goods? The case of Estonia*
}

\author{
Piotr Gabrielczak^, Tomasz Serwach*
}

\begin{abstract}
The goal of this article is to assess the impact of the euro adoption on the complexity of goods in Estonian exports. Ricardian and Heckscher-Ohlin models of trade would predict that such a policy decision (seen as an example of trade liberalization) may result in specialization in the production of either more or less sophisticated goods - the effect depends on country's technological advancement and factor endowment. At the same time intensified FDI flows may enhance engagement of a country in international production chains with ambiguous consequences for exports complexity. Since it is impossible to a priori predict the effect monetary integration may have on the complexity, it is reasonable to conduct an empirical (and a posteriori) analysis. The authors applied the Synthetic Control Method to compare the observedpost-adoption levels of exports complexity in Estonia with the counterfactual values with Estoniaremaining outside of the Eurozone. The obtained results show that the adoption of the euro has resulted inthe increase in complexity of exported goods (compared to counterfactual scenario).
\end{abstract}

KEYWORDS: euro, international trade, complexity, treatment, Estonia

JEL CLASSIFICATION: C21, F14, F15

\section{Introduction}

Theory and empirical research into international trade has significantly evolved in recent decades. The researchers' interest has moved from trade as such towards more detailed aspects of such flows. Composition of export structure is a largely intriguing problem, and one of the most important characteristics of that matter is the level of complexity of exported goods. There are reasons to believe that specialising in more complex goods fosters growth and development. Trade flows are affected by many factors, but regional integration is one of the crucial elements of creating environment for international exchange of goods. It is believed that the increase of export complexity might be a result of economic integration

\footnotetext{
${ }^{*}$ This work was supported by the National Science Centre of Poland (Narodowe Centrum Nauki) under Grant 2014/13/N/HS4/02977.

^Department of Macroeconomics, Institute of Economics, University of Lodz

* Department of International Trade, Institute of Economics, University of Lodz
} 
between countries. However, such statement still requires empirical testing, before it could be considered a fact. In this paper we focus on the effect of entering the Eurozone on Estonian export complexity. Our aim is to verify the hypothesis, that adopting euro facilitated growth of export complexity in that country.

In the second section, we present literature review, referring first to contemporary findings on export complexity, and then to relation of euro adoption and international trade. The third section presents current trends of the Economic Complexity Index in Estonia. The fourth section describes the utilised data and introduces our approach - synthetic control method. We discuss our main findings in the fifth section, while the sixth section concludes.

\section{Literature review}

\subsection{The importance of export complexity}

Since the seminal paper by Hausmann, Hwang \& Rodrik (2007) economic complexity has become one of the most promising areas of research on the causes of economic growth. Complexity may be defined in two ways: as technological advancement of the exported goods (Lall, 2000) or as the width of components used for production (Hausmann, Hwang \& Rodrik, 2007). Both definitions are correlated, because more technologically advanced processes usually require more production stages and more input variety.

It has been argued that higher complexity of goods in exports leads to a more dynamic growth of income per capita. That effect may be especially seen in countries that liberalized their trade policies and avoided overvaluation of their currencies (see Anand, Mishra \& Spatafora, 2012). What is more, complexity of exports is linked not only to growth but also to the level of GDP per capita, as documented by Hidalgo \& Hausmann (2009).

Apart from growth, the sophistication of exports can be seen as shock absorber. According to Koren \& Tenreyro (2013) more complex exported goods can be resistant to supply side shocks. This is because more complex products, with larger variety of inputs, are less dependent on each single component. Moreover, among numerous inputs the most of them are substitutable, which means that they can be easily replaced in the time of a supply side shock.

In order to influence the export complexity, one must find the determinants of that trade feature. In general, it depends on the range of competence available in the national economy (Hidalgo \&Hausmann, 2009). This implies that export complexity requires both technological advancement and high human capital (Anand, Mishra \& Spatafora, 2012).It seems that also 
educational and R\&D policies may be of great importance. However, it must be stated that it easier to develop new comparative advantages that are close to their initial specialization, with new export goods being related to older ones (Hausmann\& Klinger, 2007). Some competences that are non-existent in a particular economy can be transferred internationally (Hidalgo \& Hausmann, 2011) and such a process in natural e.g. within transnational corporations (Costinot, Oldensky \& Rauch, 2009).

The level of technological advancement also depends on natural resources. In spite of some doubts concerning possible negative consequences of overdependence on those resources, many research results prove that it has positive economic effects (see Lederman\& Maloney, 2012). It has also been pointed that high institutional quality enables successful implementation of more complicated production processes in the economy, stimulating export complexity as well (Costinot, 2009). The pioneers of the analyses of economic complexity, Hausmann, Hwang \&Rodrik (2007), suggested a set of determinants ofthat phenomenon that includes: country size (proxied by area and population), human capital index, rule of law index and GDP per capita.

The question that has not been posed in the literature is whether economic integration stimulates higher complexity of exports. To the best of our knowledge, there is no study on thattopic. There are, however, studies that may be helpful in answering mentioned question. Young (1991) showed that trade liberalization leads developing countries to specialize in traditional sectors that exhausted their learning-by-doing opportunities. It seems reasonable to assume that those sectors produce less sophisticated - and less complex - goods. Similarly, Galor \& Mountford (2008) analysed the patterns of countries' accumulation after trade liberalization. They found that lowering of trade barriers in developing countries leads to less investment in human capital and specialization in less advanced sectors. It would suggest that after the Eurozone accession Estonia should have achieved lower exports complexity.

On the other hand, the adoption of a single currency may also result in changes in FDI flows across countries. Xu \& Lu (2006), Harding \& Javorcik (2012) and Eck \& Hubert (2016) found that FDI inflows bring about higher exports quality and sophistication. Due to the fact that economic integration may result in an increase in FDI from third countries (see Antras\& Foley, 2011), one may think of Estonia as the recipient of FDI from non-member states. 
The adoption of the euro by Estonia may be regarded as a unique example of economic integration leading to trade and factor movement liberalization. Since the literature is inconclusive, we tried to verify if the accession to the Eurozone had an impact on exports complexity in Estonia.

\subsection{The impact of the euro adoption on trade}

The creation of the euro has sparked the economists' interest in trade effects of the formation of currency unions. Probably the first attempt to quantitatively assess those effects was Rose (2000).Using the gravity model of trade, he found that the establishment of a currency unions increases bilateral trade between member countries by $200 \%$. Given such a spectacular but implausible result, other economists remained sceptical and tried to eliminate various methodological shortcomings of Rose's study - ultimately diminishing the euro trade effect (see, for example, Micco, Ordoñez \& Stein, 2003, De Nardis \& Vicarelli, 2003, Santos Silva \& Tenreyro, 2006, Berger \& Nitsch, 2008, Glick \& Rose, 2016). It is a consensus view, nowadays, that the establishment of the Eurozone increased bilateral trade between member states by only 15-30\% (see Baldwin, 2006, and Frankel, 2010, for an overview), although several studies found no effect of the Eurozone (see Santos Silva \&Tenreyro, 2010).

The method applied by us, the Synthetic Control Method, has also been utilized to assess the euro trade effect ${ }^{1}$. Saia (2016) analysed bilateral flows between seven countries that adopted the euro in 1999. According to the results obtained, the euro has led to more trade between member states compared to the counterfactual scenario based on the synthetic control groups.

The other branch of the literature is focused on the firm-level effects of the elimination of national currencies. Those studies usually analyse firms' decisions whether to export or not. The theoretical background of the papers belonging to that class is the so called New new trade theory or Trade theory with heterogeneous firm that was developed by Melitz (2003). To the best of our knowledge, however, the impact of nominal exchange rate volatility on firms' export behaviour has not been analysed. Few authors investigated the level of nominal exchange rate and its consequences for firm's engagement in exports (see, especially, Chaney, 2016). The only heterogeneous-firms trade model that directly touches on the Eurozone experience is Bergin and Lin (2012). The authors analyse the elimination of transaction costs after the formation of the EMU. Nominal exchange rate volatility can also be treated as

\footnotetext{
${ }^{1}$ The same method was also used by Gomis-Porqueras and Puzzello (2015) who studied the impact of the euro on GDP per capita in member states. Similar topic, but with the focus on Slovakia, was the research area explored by Žúdel and Melioris (2016) - they also used the Synthetic Control Method.
} 
another source of uncertainty influencing firm-level trade (that research area has been explored by, for example, Crozet, Koenig \& Rebeyrol, 2008, and Segura-Cayuela \& Vilarrubia, 2008). For the deep overview of the interactions between exchange rates and trade see Auboin \& Ruta (2013).

Putting those papers into a broader context, one may treat them as the examples of studies decomposing the euro trade effect and focusing on only some of its aspects. The firm's decision to engage in international trade constitutes the so called extensive margin of trade (number of exporters/importer or number of goods in exports/imports). The New Goods Hypothesis has been verified by, among others, Baldwin \& DiNino (2006), Flam \& Nordström (2007) and Nitsch (2007). Other implications of the adoption of a common currency that have been tested are, among others, pricing policy of exporters (Berman, Martin \& Mayer, 2012), the quality of exports (Ito \& Okubo, 2016) (see also Baldwin, DiNino, Fontagné, De Santis \& Taglioni (2008),Fontagné, Mayer \& Ottaviano (2009), Berman, Martin \& Mayer (2012) for the overview of many aspects of trade). However, to the best of our knowledge, the study of the impact of the accession to the Eurozone on the complexity of exported goods is still lacking, hence our analysis fills an important scientific gap.

Unfortunately, Estonia has not been seen as an important case for research of the euro trade effects. Analyses of the Estonian experience are non-existent in the literature that is mainly focused on the "old" member countries. There several papers, however, investigating the effects of the adoption of the euro by "new" members like Slovenia or Slovakia. Cieślik, Michałek \& Michałek (2013) used a probit model to find the determinants of export decisions of Slovenian and Slovakian firms. According to the results, the adoption of the euro by Slovenia increased the probability of engagement in export by analysed firms.

Cieślik, Michałek \& Mycielski (2014) also studied the experience of new member states. Utilising the panel model for a broad range of countries, including Slovenia. They used several specifications of the model and found no evidence that the elimination of the national currency stimulated bilateral trade between a new member and other countries belonging to the EMU. In another study (Cieślik, Michałek \& Mycielski, 2012) they concentrated on Slovakia and Slovenia and used panel data techniques(fixed effects, random effects and Hausman-Taylor estimators) to find whether analysed countries experienced trade expansion after the euro adoption. They found no evidence of such an effect. 


\section{ECI in Estonia - descriptive statistics}

In order to describe the complexity of Estonian exports we used the Economic Complexity Index (ECI) calculated by the Atlas of Economic Complexity (AEC). That indicator is based on similar assumptions as EXPY introduces by Hausmann, Hwang \& Rodrik (2007). The main advantages of ECI are: (i) its coverage - it serves as a measure of export sophistication for 124 countries in 1995-2014 period, (ii) its construction - for example, product ubiquity is calculated not by its share in world trade as in EXPY, but by the number of countries that have a comparative advantage in the production of that good.

Estonian ECI achieved its lowest level in 2000 (0.407) and the highest (0.950) in 2014. As Figures 1 and 2 present, some variation in the value of the indicator was transitory and decomposing the time series (using Hodrick-Prescott filter with usual parameters for yearly data) one may obtain trend and cyclical component. It can be seen that Estonia experienced an almost non-interrupted upward trend with the only exception in 2008 when the trend value was slightly lower compared to the previous year (0.710 in 2008 and 0.712 in 2007). The cyclical component is the difference between actual values and trend. That gap was the highest in 2000 when it ECI was 0.121 below the trend.

Figure 1. ECI and its trend - Estonia, 1995-2014

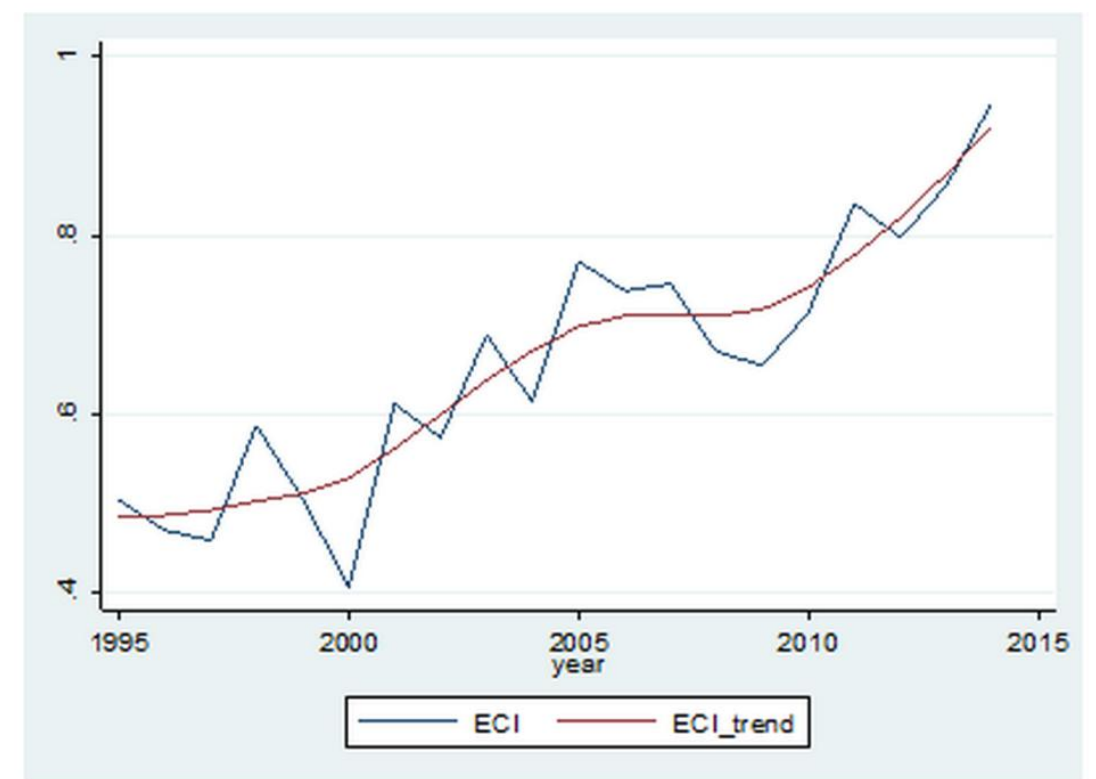

Source: Authors' calculation 
Figure 2. The cyclical component of ECI - Estonia, 1995-2014

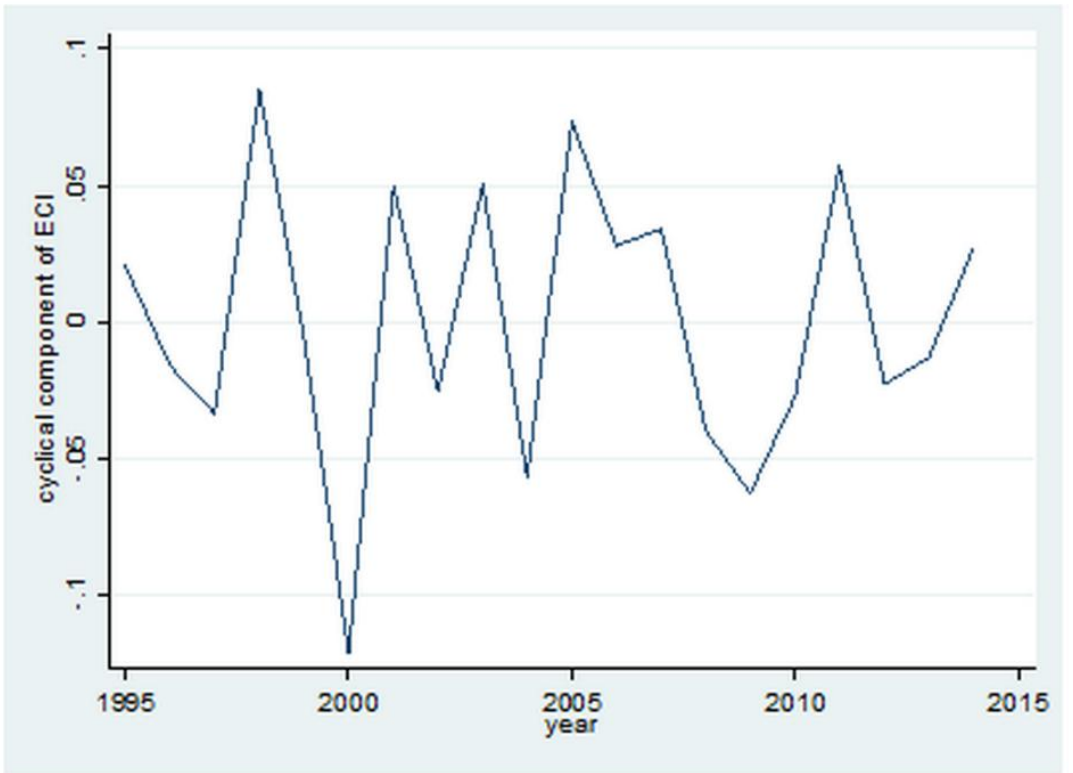

Source: Authors' calculation

The time horizon of the whole analysis may be split into two sub-periods - before and after the adoption of the euro (see Table 1 and 2). One may notice that the volatility of ECI (both the aggregate value and trend) was higher in pre-euro time. Since the accession to the Eurozone Estonian exports complexity has more than halved.

Table 1. ECI in Estonia - descriptive statistics

\begin{tabular}{|l|c|c|c|c|}
\hline \multicolumn{1}{|c|}{ Period } & $\begin{array}{c}1995-2014 \\
\text { (the whole sample) }\end{array}$ & $\begin{array}{c}2011-2014 \\
\text { (after the adoption } \\
\text { of the euro) }\end{array}$ & $\begin{array}{c}1995-2010 \\
\text { (before the adoption } \\
\text { of the euro) }\end{array}$ & $\begin{array}{c}\text { 1995-2003 } \\
\text { (before the EU } \\
\text { accession) }\end{array}$ \\
\hline Mean & 0.658 & 0.859 & 0.607 & 0.534 \\
\hline Standard deviation & 0.146 & 0.065 & 0.113 & 0.088 \\
\hline $\begin{array}{l}\text { Coefficient } \\
\text { of variation }\end{array}$ & $22.28 \%$ & $7.51 \%$ & $18.60 \%$ & $16.48 \%$ \\
\hline
\end{tabular}

Source: Authors' calculation

Table 2. The trend component of ECI in Estonia - descriptive statistics

\begin{tabular}{|l|c|c|c|c|}
\hline \multicolumn{1}{|c|}{ Period } & $\begin{array}{c}1995-2014 \\
\text { (the whole sample) }\end{array}$ & $\begin{array}{c}2011-2014 \\
\text { (after the adoption } \\
\text { of the euro) }\end{array}$ & $\begin{array}{c}1995-2010 \\
\text { (before the adoption } \\
\text { of the euro) }\end{array}$ & $\begin{array}{c}1995-2003 \\
\text { (before the EU } \\
\text { accession) }\end{array}$ \\
\hline Mean & 0.658 & 0.859 & 0.610 & 0.533 \\
\hline Standard deviation & 0.134 & 0.062 & 0.099 & 0.055 \\
\hline $\begin{array}{l}\text { Coefficient } \\
\text { of variation }\end{array}$ & $20.31 \%$ & $7.22 \%$ & $16.24 \%$ & $10.25 \%$ \\
\hline
\end{tabular}

Source: Authors' calculation

The increase in ECI after the adoption of the euro should not be treated as the indication that the single currency led to such a change. Estonia had experienced an upward trend even 
before that country entered the Eurozone. That is why the more scrutinizes analysis is needed to evaluate the impact of that decision on exports complexity. With that in mind, we adhered to the SCM as the analytical tool.

\section{Data and methodology}

\subsection{The description of the data}

The outcome variable of our research is export complexity. We chose ECI as its measure. However, since our main interest was to determine long-term, stable changes in complexity after entering the Eurozone, and ECI is a subject to significant cyclical volatility, we used the trend filtered out from ECI with standard annual Hodrick-Prescott filter.

Our set of covariates was based on Hausmann, Hwang \& Rodrik (2007), and it included information about population, real GDP per capita and Human Capital Index, derived from the Penn World Table 9.0 (Feenstra, Inklaar \& Timmer, 2015), data on the countries' area from CEPII GeoDist Database (Mayer \& Zignago, 2011) and the Rule of Law Index estimates drawn from the World Bank's Worldwide Governance Indicators database.

These covariates meet conditions required by the SCM (Campos, Coricelli \& Moretti, 2014), since they, as it has been proved by Hausmann, Hwang \& Rodrik (2007), determine the path of outcome variable well and they do not strongly anticipate the intervention, which was entering the Eurozone. Of course, minimal anticipation is impossible to avoid, because political decisions are often announced in advance and most economic variables depend on expectations about the future. However, since integration is a continuous problem and not a binary one, minimal immanent anticipation can be accepted for SCM procedure (Campos, Coricelli \& Moretti, 2014).

Another problem is the choice of control set of countries. As stated by Campos, Coricelli\& Moretti (2014), control sample must not include countries that could be affected by the treatment themselves. Moreover, unit zero country should not be an outlier in the sample. This is partially problematic, because Estonia is a small country. All things considered, our control set consisted of 12 countries, 10 being non-European states (Australia, Canada, Chile, Israel, Japan, Korea, Mexico, New Zealand, Turkey, USA) and 2 being European but non-EU members (Norway, Switzerland). The scope of our research is limited to years 1995-2014 by the availability of the ECI data. 


\subsection{Methodology}

In our research we apply synthetic control method (SCM), suggested by Abadie, Diamond \& Hainmueller (2010). This method was created for panel data analysis to allow modelling more complex responses to shocks, than in typical fixed effects or difference in difference (DD) approaches, however with restrictions that country-specific effects are limited to one country and time-varying effects are continuous in time (once introduced - they remain unchanged). These restrictions mean, that SCM could be used to evaluate effects of policy decisions, such as introducing new regulations in one of the countries.

Let us assume, that we observe $\mathrm{J}+1$ units in $\mathrm{T}$ periods. Let us assume that unit zero was a subject to some kind of treatment (e.g. political decision) in period $\mathrm{T}_{0}$. In such a case, units $1, \ldots, \mathrm{J}$ are the control sample and the effects of treatment (interference) are observed in unit zero for periods $T_{0}, \ldots, T$, while they remain unobserved in periods $0, \ldots, T_{0}-1$. Let $Y_{\text {it }}$ be the observed variable which might have two outcomes: $\mathrm{Y}_{\mathrm{it}}{ }^{\mathrm{N}}$ (neutral outcome, without the effect of interference) and $\mathrm{Y}_{\mathrm{it}}^{\mathrm{I}}$ (interfered outcome with treatment effects included). Let $\mathrm{D}_{\mathrm{it}}$ be a binary function and $\Delta_{\text {it }}$ be a difference of two potential outcomes for country $\mathrm{i}$ in period t. We can formulate initial conditions as below.

$$
\begin{aligned}
& \text { (1) } Y_{i t}=Y_{i t}^{N}+\Delta_{i t} D_{i t} \\
& \text { (2) } \Delta_{i t}=Y_{i t}^{I}-Y_{i t}^{N} \\
& \text { (3) } D_{i t}=\left\{\begin{array}{c}
1 \text { if } i=0 \text { and } t=T_{0}, \ldots, T \\
0 \text { otherwise }
\end{array}\right.
\end{aligned}
$$

The philosophy of SCM is to model the potential neutral outcome for post-treatment periods, while taking empirical outcomes as interfered ones. In that case $\Delta_{\mathrm{it}}$ is the measure of treatment effect. Factor model for neutral outcome can be specified as below.

(4) $Y_{i t}^{N}=\delta_{t}+Z_{i} \theta_{t}+\lambda_{t} \mu_{i}+\epsilon_{i t}$

In this model $\delta_{\mathrm{t}}$ is an unobserved common but time-varying factor, while $\lambda_{\mathrm{t}} \mu_{\mathrm{i}}$ represents heterogeneous responses to multiple unobserved factors. $Z_{i}$ denotes covariates with timevarying parameters $\theta_{t}$, and $\varepsilon_{i t}$ stands for an error term. Should one assume that $\lambda_{\mathrm{t}}$ is constant in time, equation (4) changes into a standard DD model, which leads to a conclusion that SCM can be treated as generalised DD approach. 
The idea of SCM is to compare pre-treatment outcomes and characteristics of unit zero and the control sample and create a set of weighs that would allow building synthetic unit zero as a weighted average of the control sample units. The weighs need to be all non-negative and summing up to 1 to ensure that the synthetic unit zero lies within a convex hull of the control set - that is why it is vital to compose the control set making sure, that unit zero is not an outlier or an extreme case in the entire sample of analysed countries (Fremeth, Holburn \& Richter, 2013). The pre-treatment outcomes and characteristics for synthetic unit zero should be close to actually observed unit zero parameters. Defining $Y_{i}^{k}$, with $k=1, \ldots, m$ as a family of linear functions of the pre-treatment outcomes, we can formalise the condition for optimal weights as below.

(5) $W^{*}=\left(w_{1}^{*}, \ldots, w_{J}^{*}\right) ; \sum_{i=1}^{J} w_{i}^{*} Z_{i}=Z_{0}, \sum_{i=1}^{J} w_{i}^{*} Y_{i}^{1}=Y_{0}^{1}, \ldots, \sum_{i=1}^{J} w_{i}^{*} Y_{i}^{m}=Y_{0}^{m}$

Should condition (5) be perfectly met, we would obtain an approximately unbiased estimator of the $\Delta_{\text {it }}$ for unit zero.

(6) $\hat{\Delta}_{0 t}=Y_{0 t}-\sum_{i=1}^{J} w_{i}^{*} Y_{i t}, t=T_{0}, \ldots, T$

Unfortunately, in reality it is hardly possible to find such a weight combination. However, let us takea vector of characteristics of the treated country $\mathrm{X}_{0}$, defined as $\left(\mathrm{Z}_{0}, \mathrm{Y}_{0}{ }^{1}, \ldots, \mathrm{Y}_{0}{ }^{\mathrm{m}}\right)^{\prime}$ and a matrix of the same characteristics for the $\mathrm{J}$ control sample countries $\mathrm{X}_{\mathrm{J}}$. The estimator (6) holds, when we choose a weight vector that solves optimization problem underneath.

(7) $\quad W=\left(w_{1}, \ldots, w_{J}\right) ; \forall_{i=1, \ldots, J} w_{i} \geq 0 \wedge \sum_{i=1}^{J} w_{i}=1$

(8) $\widehat{W}=\min \left\|X_{0}-X_{J} W\right\|$

Condition (8) is a general one. More operationally, the distance between $\mathrm{X}_{0}$ and $\mathrm{X}_{\mathrm{J}} \mathrm{W}$ could be expressed using quadratic form.

(9) $\widehat{W}=\min \left\{\left(X_{0}-X_{J} W\right)^{\prime} V\left(X_{0}-X_{J} W\right)\right\}$

$\mathrm{V}$ is a symmetric and positive semi definite matrix, which can be interpreted as a measure for the relative importance of characteristics included in the $\mathrm{X}_{0}$ vector and $\mathrm{X}_{\mathrm{J}}$ matrix (Campos, Coricelli\& Moretti 2014). The choice of V is arbitrary, however it is a standard practice to choose $\mathrm{V}$ that minimises the mean squared error in the pre-treatment period. 


\section{Results}

\subsection{Basic results}

We applied SCM procedure using 'synth' command in STATA. Our outcome variable was ECI trend - ECI time series smoothened with Hodrick-Prescott filter. Our choice of covariates was based on Hausmann, Hwang \& Rodrik (2007). To obtain a better fit, SCM allows including pre-treatment outcome values as control variables. However, as stated by Kaul, et al. (2016), one should be cautious, as controlling for full set of pre-treatment outcome values results in total insignificance of any other variables included. If these other covariates are in fact significant determinants of the outcome value, than such a case might lead to a bias of the synthetic counterfactual in the post-treatment period. Kaul, et al. (2016) suggest either using an average level of outcome values in the pre-treatment, or limiting to controlling for just a few outcome values, preferably at the end of pre-treatment period.

Filtered Estonian ECI has a strong upward trend throughout the entire pre-treatment period, therefore utilizing the first solution by Kaul, et al. (2016) resulted in poor fit of the pretreatment synthetic ECI and actual ECI values. That is why we decided to include rather only extreme values from pre-treatment. Global minimum for the pre-treatment period was in 1995 and global maximum in 2010. The straight trend of filtered Estonian ECI has also had one small disturbance, resulting in local maximum in 2007 and local minimum in 2008 - very close to the end of the pre-treatment. Eventually, filtered ECI values for 1995 and period 2007-2010 were used to facilitate a better fit in accordance with the second suggested approach $^{2}$. Results of the SCM procedure are presented in Figure 3.

\footnotetext{
${ }^{2}$ We have experimented with other combinations of pre-treatment outcome values, however none of the estimations gave significantly different result than the original idea. Moreover, similarly to smoothening ECI series we have used Hodrick-Prescott filter on covariates used in the research. Again, the main findings remained unchanged. That is probably because none of the utilised covariates (area, population, GDP per capita, Human Capital Index, Rule of Law Index) is a subject to volatility comparable to that of ECI. In other words, filtered time series were not dissimilar to their analogues incorporating cyclical components. We have also tried SCM procedure based only on full set of pre-treatment ECI values, once more obtaining approximate effects. These observations alone may indicate robustness of our results.
} 
Figure 3. Synthetic and actual values of filtered Estonian ECI

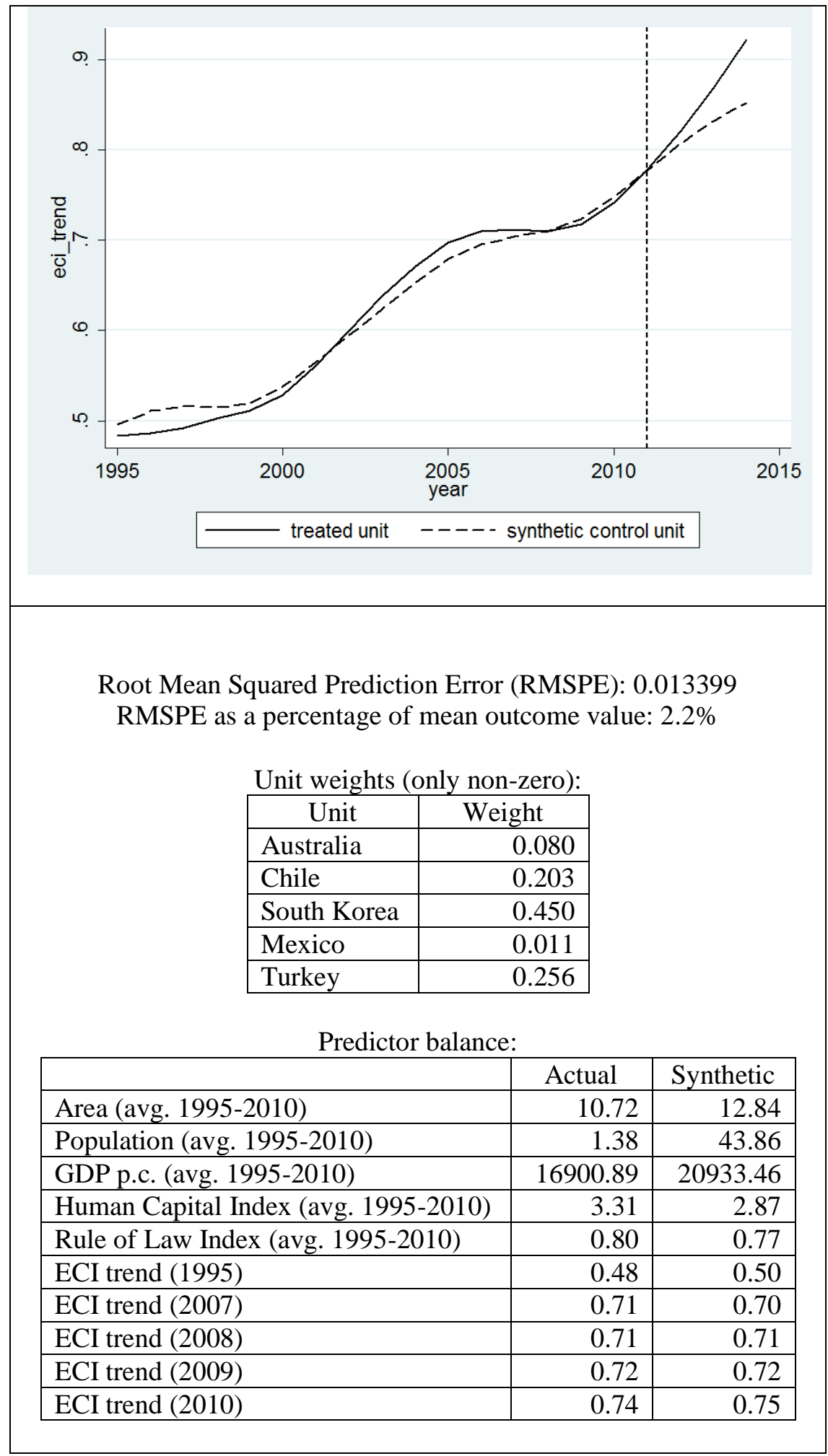

Source: Authors' calculation

Synthetic Estonia has a very good fit in reference to ECI values, which is proven by low RMSPE and the proximity of the controlled actual and synthetic ECI values. Synthetic Estonia also has Rule of Law and Human Capital Indices only slightly below actual values, 
while its area and GDP per capita are larger. Probably the biggest misfit can be observed when analysing population. That is because Estonia has a relatively small population and in terms of this characteristic it is an outlier in most pools of countries with available data. Considering all, synthetic Estonia seem to fit actual Estonia well in the pre-treatment period, which means that it might serve as a good reference point in the post-treatment years.

One can clearly notice, that while both actual and synthetic Estonia maintain their initial growing trends of ECI, counterfactual scenario of not adopting Euro resulted in lower ECI dynamics and in consequence lower complexity of export. It seems that Estonian economy was on a path of constant evolution towards specialisation in more complex goods since 1995, and probably even since its secession from USSR and economic transformation. This increase of complexity has been decelerated when Estonia entered the EU, probably because of reduction of trade barriers and a change in comparative advantages. Estonia, despite its dynamic development, is still significantly less developed than the 'old' EU member states, that is why its specialisation after joining the common market temporarily reverted towards less complex goods. However after the economic crisis Estonian ECI returned to its pattern of quick growth. Entering Eurozone facilitated that growth by reducing trade risk and allowing even stronger export orientation and specialisation. Since more complex goods are also considered more advanced, more shock-resistant and more profitable, we can conclude that adopting Euro turned out most beneficial for Estonia, at least when referring to its export.

\subsection{Robustness}

We checked the robustness of obtained results, using placebo test suggested by Abadie, Diamond \& Hainmueller (2010). That test is based on the application of the SCM procedure to every unit belonging to the donor pool. In other words, the procedure is similar to a permutation test. As a starting point the treated unit (Estonia in our case) must be excluded from the donor pool. The remaining units are seen as a new donor pool that is used in such a way that each unit is treated as if the intervention occurred. The differences between actual outcome and synthetic values are analysed to verify the null hypothesis that the intervention had no effect. In our study the null hypothesis states that the adoption of the euro had no impact on the complexity of exports in Estonia. That hypothesis would be proved wrong if the gaps between estimated treatment effects and calculated placebo effects were small.

Figure 4 presents the results of the placebo test. Red bold line are ECI (HP-filtered) gaps for Estonia and the other lines are gaps for placebo units. To conduct the placebo test we used 
MSCMT package in R described in detail in Becker and Klößner (2016). Those control units that had pre-treatment RMSPE of more than 10 times the Estonian pre-treatment RMSPE were excluded. It means that we included only those placebo units that had a relatively good fit in years 1995-2010.

Figure 4. Placebo test results for the Eurozone accession effects on Estonian ECI

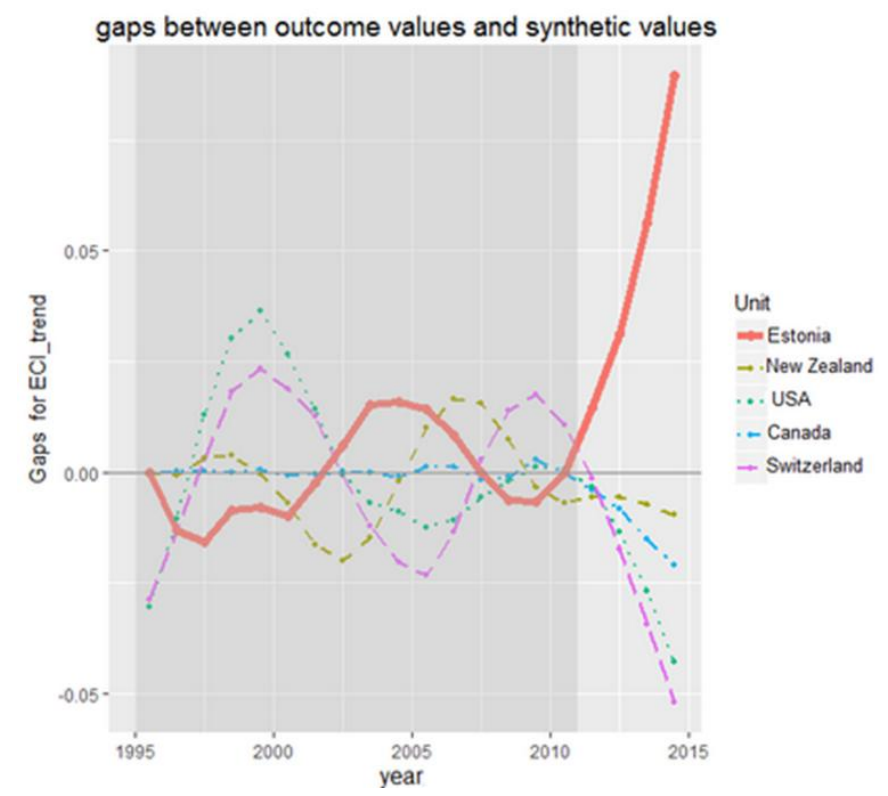

Source: Authors' calculation

As Figure 4 illustrates, the gaps for Estonia were significantly different from the gaps for placebo units. Estonia as the only country had differences between outcome and synthetic values indicating the positive impact of the euro adoption on ECI. Other countries had negative gaps meaning the opposite sign. Those stark discrepancies between Estonia and placebo units prove that the results obtained for Estonia are robust.

\section{Summary of findings}

The aim of the article was to verify if adopting euro may have stimulated complexity of Estonian export. The research was conducted with SCM, which allowed us to make sound conjectures on what might have happened had Estonia not accessed the Eurozone. Both, synthetic counterfactual Estonia and the actual country, maintained the growing trend of ECI in the post-treatment period. However, the pace of ECI increase in actual Estonia that had switched to euro was undoubtedly quicker. These results were robust.

In our opinion, Estonia's export complexity is developing ever since that country regained its independence from USSR. That growing trend has been inhibited after joining EU because of 
reallocation of trade towards better developed countries, which altered Estonian comparative advantages. However, as soon as Estonia has joined the Eurozone, the values of its ECI have again climbed with high dynamics. We believe that reduction of exchange rate risk in international trade might have allowed a return to quick development patterns.

\section{References}

Abadie, A., Diamond, A., Hainmueller, J. (2010) "Synthetic Control Methods for Comparative Case Studies: Estimating the Effect of California's Tobacco Control Program", Journal of the American Statistical Association, Vol. 105, No. 490, pp. 493-505.

AEC, Atlas of Economic Complexity, Center for International Development at Harvard University, http://www.atlas.cid.harvard.edu.

Antras, P., Foley, F.C. (2011) "Regional Trade Integration and Multinational Firm Strategies" [in:] Barro, R., Lee, J.-W. (eds.) "Costs and Benefits of Economic Integration in Asia”, Oxford University Press, Oxford.

Aristovnik, A., Meze, E. (2009) “The Economic and Monetary Union's Effect on (International) Trade: The Case of Slovenia Before Euro Adoption”,MPRA Paper No. 17445 .

Anand, R., Mishra, S., Spatafora, N. (2012) "Structural Transformation and the Sophistication of Production", IMF Working Paper No. 12/59.

Auboin, M., Ruta, M. (2013) "The relationship between exchange rates and international trade: a literature review”, World Trade Review, Vol. 12, No. 3, pp. 577-605.

Baldwin, R. (2006) The Euro's Trade Effects", ECB Working Paper No. 594.

Baldwin, R., DiNino, V. (2006) "Euros and zeros: The common currency effect on trade in new goods", NBER Working Papers No. 12673.

Baldwin, R., DiNino, V., Fontagné, L., De Santis, R., Taglioni, D. (2008) "Study on the Impact of the Euro on Trade and Investment", European Economy. Economic papers No. 321 .

Becker, M., Klößner, S. (2016) “Computing Generalized Synthetic Controls with R package MSCMT", Saarland University, mimeo.

Berger, H., Nitsch, V.(2008)"Zooming out: The trade effect of the euro in historical perspective", Journal of International Money and Finance, Vol. 27, No. 8, pp. 12441260. 
Bergin, P., Lin, C.Y. (2012)"The dynamic effects of a currency union on trade", Journal of International Economics, Vol. 87, No. 2, pp. 191-204.

Berman, N., Martin, P., Mayer, T. (2012), "How Do Different Exporters React to Exchange Rate Changes", Quarterly Journal of Economics, Vol. 127, No. 1, pp. 437-492.

Campos, N.F., Coricelli, F., Moretti, L. (2014), "Economic Growth and Political Integration: Estimating the Benefits from Membership in the European Union Using the Synthetic Counterfactuals Method", IZA Discussion Paper No. 8162.

Chaney, T. (2016) "Liquidity constrained exporters", Journal of Economic Dynamics \& Control, in press.

Cieślik, A., Michałek, J., Michałek, A. (2013)“The Impact of the Common Currency on Exports on New EMU Members: Firm-level Evidence for Slovenia and Slovakia”, Equilibrium. Quarterly Journal of Economics and Economic Policy, Vol. 8, No. 4, pp. $7-23$.

Cieślik, A., Michałek, J., Mycielski, J.(2012) "Trade effects of the euro adoption in Central and Eastern Europe", Journal of International Trade \& Economic Development, Vol. 21, No. 1, pp. 25-49.

Cieślik, A., Michałek, J., Mycielski, J. (2014) "Trade effects of the euro adoption", Bank $i$ Kredyt (Bank \& Credit), Vol. 45, No. 4, pp. 331-348.

Costinot, A. (2009) "On the origins of comparative advantage", Journal of International Economic, Vol. 77, pp. 255-264.

Costinot, A., Oldensky, L., Rauch, J.E. (2009) “Adaptation and the Boundary of Multinational Firms", NBER Working Paper No. 14668.

Crozet, M., Koenig, P., Rebeyrol, V.(2008) "Exporting to Insecure Markets: a Firm-Level Analysis", CEPII Working Paper No.2008-13.

De Nardis, S., Vicarelli, C.(2003) "Currency Unions and Trade: The Special Case of EMU”, World Review of Economics, Vol. 139, No. 4, pp. 625-649.

Eck, K., Huber, S. (2016) "Product sophistication and spillovers from foreign direct investment", Canadian Journal of Economics, Vol. 49, No. 4, pp. 1658-1684.

Feenstra, R.C., Inklaar, R., Timmer, M.P. (2015) "The Next Generation of the Penn World Table", American Economic Review, Vol. 105, No. 10, pp. 3150-3182.

Flam, H., Nordström, H. (2007) "Explaining large euro effects on trade: the extensive margin and vertical specialization", mimeo.

Fontagné, L., Mayer, T., Ottaviano, G. (2009), “Of markets, products and prices. The effects of the euro on European firms", Bruegel Blueprint Series, Vol. VIII. 
Frankel, J.A. (2010)“The Estimated Trade Effects of the Euro: Why Are They Below Those from Historical Monetary Unions among Smaller Countries?" [in:] Alesina, A. Giavazzi, F. (eds.) "Europe and the Euro", University of Chicago Press, Chicago, IL.

Fremeth, A.R., Holburn, G.L.F., Richter, B.K. (2013) "Making Causal Inferences in Small Samples using Synthetic Control Methodology: Did Chrysler Benefit from Government Assistance?", mimeo.

Galor, O., Mountford, A. (2008) “Trading Population for Productivity: Theory and Evidence”, Review of Economic Studies, Vol. 75, No. 4, pp. 1143-1179.

Gertler, P. (2006) "Export Structure Quality and Economic Growth", National Economy Issues, National Bank of Slovakia, BIATEC, Vol. XIV, No. 10.

Glick, R., Rose, A.(2016) “Currency Unions and Trade: A Post-EMU Mea Culpa”, CEPR Discussion Paper No. 10615.

Gomis-Porqueras, P., Puzzello, L. (2015) "Winners and Losers from the euro", Deakin University, Faculty of Business and Law Economics Series No. 2015_2.

Harding, T., Javorcik, B. (2012) "Foreign Direct Investment and Export Upgrading", Review of Economics and Statistics, Vol. 94, No. 4, pp. 964-980.

Hausmann, R., Hwang, J., Rodrik, D. (2005) "What you export matters", NBER Working Paper No. 11905.

Hausmann, R., Hwang, J., Rodrik, D. (2007) "What you export matters", Journal of Economic Growth, Vol. 12, No. 1, pp. 1-25, doi:10.1007/s10887-006-9009-4.

Hausmann, R., Klinger, B. (2007) "The Structure of the Product Space and the Evolution of Comparative Advantage", Center for International Development at Harvard University Working Paper No. 146.

Hidalgo, C.A., Hausmann, R. (2009) "The building blocks of economic complexity", Proceedings of the National Academy of Sciences, 106(26), pp. 10570-10575.

Hidalgo, C.A., Hausmann, R. (2011) “The network structure of economic output”, Journal of Economic Growth, 16 (4), pp. 309-342.

Ito, T., Okubo, T. (2016), “The Impact of the Euro on the Quality of Trade: Evidence from the European Union”, The Manchester School, Vol. 84, No. 4, pp. 506-527.

Kaul, A., Klößner, S., Pfeifer, G., Schieler, M. (2016) "Synthetic Control Methods: Never Use All Pre-Intervention Outcomes as Economic Predictors", mimeo.

Koren, M., Tenreyro, S. (2013) “Technological Diversification”, The American Economic Review, 103(1), pp. 378-414. 
Lall, S. (2000) "The Technological Structure and Performance of Developing Country Manufactured Exports, 1985-1998”, University of Oxford Queen Elizabeth House Working Paper No. 44.

Lederman, D., Maloney, W.F. (2012) "Does What You Export Matter? In Search of Empirical Guidance for Industrial Policies”, World Bank, Washington, DC.

Mayer, T., Zignago, S. (2011) "Notes on CEPII's distances measures: The GeoDist database”, CEPII Working Paper No. 2011-25.

Melitz, M.J (2003) "The Impact of Trade on Intra-Industry Reallocations and Aggregate Industry Productivity”, Econometrica, Vol. 71, No. 6, pp. 1695-1725.

Micco, A., Ordoñez, E., Stein, G.(2003) "The Currency Union Effect on Trade: Early Evidence from EMU”, Economic Policy, Vol. 18, No. 37, pp. 315-356.

Mundell, R.A. (1961) “A Theory of Optimum Currency Areas”, The American Economic Review, Vol. 51, No. 4, pp. 657-665.

Nitsch, V. (2007) “Monetary Integration and Trade: What Do We Know?", Paper for the DIE conference on "Regional Economic Integration Beyond Europe" (Zürich, December 2007).

Rose, A. (2000) "One money, one market: The effect of currency unions on trade", Economic Policy, Vol. 15, No. 30, pp. 7-46.

Saia A. (2016) "Choosing the Open Sea: The Cost to the UK of Staying Out of the euro", University of Bologna, mimeo.

Santos Silva, J., Tenreyro, S. (2006) "The Log of Gravity", Review of Economics and Statistics, Vol. 88, No. 4, pp. 641-658.

Santos Silva, J., Tenreyro, S. (2010) “Currency Unions in Prospect and Retrospect”, Annual Review of Economics, Vol. 2, pp. 51-74.

Segura-Cayuela, R., Vilarrubia, J.M. (2008) "Uncertainty and entry into export markets", Banco de España Working Paper No. 0811.

Worldwide Governance Indicators, World Bank: World Data Bank, http://databank.worldbank.org/data/reports.aspx?source=worldwide-governanceindicators.

$\mathrm{Xu}, \mathrm{B} ., \mathrm{Lu}, \mathrm{J}$. (2006) "The impact of foreign firms on the sophistication of Chinese exports", China Europe International Business School and Tsinghua University Working Paper, Shanghai.

Young, A. (1991) "Learning by Doing and the Dynamic Effects of International Trade", Quarterly Journal of Economics, Vol. 106, No. 2, pp. 369-405. 
Žúdel, B, Melioris L. (2016), "Five Years in Balloon: Estimating the Effects of Euro Adoption in Slovakia Using the Synthetic Control Method", OECD Economics Department Working Paper No. 1317. 